\title{
2020: projetando o novo normal (o futuro é agora)
}

\author{
na melhor das hipóteses, \\ a obra de arte surge através da montagem \\ Walter Benjamin \\ Se no Ocidente o design reflete o ser humano \\ que intervém no mundo, \\ no Oriente coincide com o modo como o ser humano emerge \\ e se eleva do mundo para fazer dele objeto de experiência \\ Vilém Flusser
}

To Design foi eleito como base aos números da Revista Vazantes em 2020. Ou seja, os gestos do projetar fundamentaram as chamadas aos dois números neste ano das transmissões, recebendo contribuições de 31 doutores, a publicação em português de Visualizing Vertov (traduzido pelos bolsistas de Projet'ares Audiovisuais, com autorização de Lev Manovich), a entrevista com Marc Lee e 13 Proposições Poéticas.

Além dos artigos e ensaios (verbais e/ou visuais), este segundo número da Revista Vazantes em 2020, com o dossiê temático Fronteiras do projetar: diálogos entre arte e design, traz um texto curatorial de Graziela Mello (UFMG) sobre as três Artes Sonoras submetidas junto à inauguração da galeria de vídeos e/ou sonoridades - http://periodicos.ufc.br/vazantes/ galeria. Assim, se a capa anterior jogara com as planificações (visualização automatizada via diagramas no ImageJ) desde as

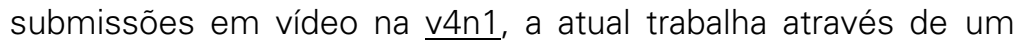
remix composicional desde a obra "Re - Vinil". Projetares nas Artes, seguimos os campos transversais entre o Audiovisual e o Design, onde compreendemos que o cinema não apenas, cada dia mais, se torna design, como as vanguardas operacionalizavam nas lógicas diagramares do projeto: ofício de artista. 
Em tempos de de(s)colonizações - quando novas epistemologias e ticketmentalität são aplicados -, este início do século XXI se encontra novamente sob binarismos e guerras ideológicas dentre fetiches tecnológicos e pandemia generalizada, acarretando na COVID-19. A inteligência artificial tornou-se a forçamotriz de nossos dias que poderia sugerir tratar-se de uma ficção científica, se não fosse, entretanto - entre fake news, mortes e lives -, o presente já nosso premeditado futuro. Ao futuro, reservamos a publicação de duas recentes traduções realizadas pelo nosso corpo discente - durante os encontros remotos em confinamento -, que vislumbram revisão:

- Why Appropriation? e Infallible Processes: What Writing Can Learn From Visual Art - Uncreative Writing, de Kenneth Goldsmith (por Renan de Oliveira e Wilker Paiva)

- En el trasfondo de nuestra cultura: la tradición racionalista y el problema del dualismo ontológico, de Arturo Escobar (por Nilo Lima, Sérgio Rodriguez, Natália Cohel, Germana Brito, Jander Alcântara e Renata Cavalcante)

Aproveitamos o espaço da seção de tradução para deixarmos registradas as versões em espanhol, inglês e francês das chamadas aos dossiês temáticos de 2020, conforme foram compartilhadas em junho. Agradeço, assim, a todos que fizeram possível esta segunda edição no quarto ano da Revista Vazantes e desejo uma leitura (ou escuta) atenta às contribuições projetuais e/ou aos processos de criação détournements aqui publicados.

Nesta nova etapa de nossa era neo-biopolítica:

cuidemo-nos!

Profa. Dra. Milena Szafir

editora-responsável Revista Vazantes (2020-2021) 